\title{
1. Environmental risks and opportunities of biofuels
}

\section{Annette Cowie, Alan Cowie, Sampo Soimakallio and Miguel Brandáo}

\subsection{INTRODUCTION}

Bioenergy refers to energy products derived from biomass - including heat, electricity and biofuels, the latter term referring to liquid fuels derived from biomass, particularly ethanol and biodiesel. Biofuels are generally used for transport, though they may also be used for generation of electricity. A few countries have a long history of biofuel use: in Brazil, ethanol from sugar cane has been promoted since 1975 (40 years ago). ${ }^{1}$ The production of biofuels has expanded dramatically in recent decades. In 2013, 87.2 billion litres of ethanol, 26.3 billion litres of biodiesel and 3 billion litres of hydro-treated vegetable oils were produced globally, representing $2.3 \%$ of the use of transport fuels worldwide. ${ }^{2}$ The major ethanol producers are the USA (50.3 billion litres), Brazil (25.5 billion litres), China (2.0 billion litres), Canada (1.8 billion litres) and France (1.0 billion litres), while the largest biodiesel producers are the USA (4.8 billion litres), Germany (3.1 billion litres), Argentina (2.9 billion litres), Brazil (2.3 billion litres), France (2.0 billion litres) and Indonesia (2.0 billion litres). ${ }^{3}$

Most biofuels used currently are produced from starch, sugar or oil crops that have traditionally been grown for food. These are "firstgeneration" biofuels. Research and development of biofuels are now focused on "second-generation" or "advanced" biofuels, produced from lignocellulosic crops such as grasses and woody plants.

The growth of the biofuel industry has largely been driven by policies

\footnotetext{
1 Dufey, A., 2006, Biofuels Production, Trade and Sustainable Development: Emerging issues (IIED).

2 REN21 Secretariat, Renewables 2014 Global Status Report (Paris, 2014).

3 Ibid.
} 
that address climate change, though other objectives, including enhanced energy security and support for rural industries, are important in some jurisdictions. While conventional petroleum supplies are becoming exhausted in many regions, there is no shortage of less conventional fossil fuel options for supplying liquid fuels: deep sea petroleum; shale oil/ tar sands; coal to liquid, CNG and gas conversion. While supplies from these sources are expanding rapidly, there are concerns over the high environmental costs of these options, in terms of carbon footprint, ${ }^{4}$ and hydrological and biodiversity impacts. ${ }^{5}$ Biofuel production is expected to continue to rise in order to supply future demand for fuels for heavy transport and aviation, applications for which other renewable alternatives are not readily available. To meet the $2^{\circ} \mathrm{C}$ global warming target agreed in the Copenhagen Accord, ${ }^{6}$ it is anticipated that bioenergy (that is, all energy products from biomass) will play an increasingly significant role. ${ }^{7}$ Projections are that liquid biofuel could contribute $18-20 \mathrm{EJ} / \mathrm{year}$ in $2050,{ }^{8}$ compared with around $5 \mathrm{EJ} / \mathrm{yr}$ in $2013 .{ }^{9}$

Despite the fact that a major driver for biofuel promotion is the assumed climate change benefits, the climate change mitigation value of biofuels has been questioned. In addition, concerns have been raised over other environmental impacts of some biofuel systems. Whether produced in a firstor second-generation process, the biofuel "life cycle" involves growing or collecting biomass feedstock, processing feedstock into a liquid fuel product, distributing fuel, and combusting fuel. Environmental risks and benefits may arise at each of the life cycle stages. Furthermore, expansion

4 The carbon footprint of a product refers to the net emissions of all greenhouse gases into the atmosphere arising from the product lifecycle (ISO 2013).

5 Brandt, A.R., 2008, 'Converting Oil Shale to Liquid Fuels: Energy Inputs and Greenhouse Gas Emissions of the Shell in Situ Conversion Process', 42 Environmental Science \& Technology 7489; Wu, M. and Y. Chiu, 2011, 'Consumptive Water Use in the Production of Ethanol and Petroleum Gasoline 2011 update', Energy Systems Division.

6 UNFCCC, 'FCCC/CP/2009/11/Add.1 Decision 2/CP.15 Copenhagen Accord'.

7 GEA, 2012, Global Energy Assessment - Toward a Sustainable Future (International Institute for Applied Systems Analysis, Laxenburg, Austria and Cambridge University Press); IPCC, 2014, Summary for Policymakers. In: Climate Change 2014: Mitigation of Climate Change. Contribution of Working Group III to the Fifth Assessment Report of the Intergovernmental Panel on Climate Change (Edenhofer, O. et al. (eds), Cambridge University Press, Cambridge, United Kingdom and New York, NY, USA).

8 Creutzig, F. et al., 2015, 'Bioenergy and climate change mitigation: an assessment', 7:5 GCB Bioenergy 916.

9 Supra, n. 2. 
of biofuels has indirect effects, largely resulting from land use change. This chapter considers the positive and negative environmental effects associated with the life cycle, and indirect effects, for different biofuel systems.

\subsection{BIOFUEL BASICS: BIOFUEL PRODUCTION SYSTEMS}

There are many pathways through which biofuels may be produced. The most common pathways are fermentation to produce ethanol, or transesterification to produce biodiesel, as explained below.

Conventional ethanol production (Figure 1.1) commences with carbohydrates, in the form of sugars, or starch, which are hydrolysed into simple sugars. Sugar crops comprise sugar cane and sugar beet, while starch crops include the cereals (maize, wheat) and root crops (for example cassava). Sugars are fermented through the action of yeasts to produce ethanol (ethyl alcohol), which is separated from water by distillation or molecular sieves. The residues may be used as animal feed. Ethanol is usually mixed with gasoline at low ratio, up to $10 \%$, for vehicles designed to burn gasoline. Modified vehicles may use up to $85 \%$ ethanol. Second-generation ethanol processes use lignocellulosic biomass, such as maize stover, perennial grasses such as miscanthus and switchgrass, or short rotation woody crops that may be coppiced (willow, poplar). The complex carbohydrates of lignin and cellulose must be broken down through chemical or enzymatic hydrolysis, before the sugars can be fermented. Ethanol yields per hectare can be higher from lignocellulosic crops, but the supply chain emissions are expected to be higher and the energy balance lower, compared with "first generation" crops, because of the pre-fermentation treatment required.

Biodiesel is produced through trans-esterification of vegetable oil or animal fat (tallow) (Figure 1.2). Most commonly, the oil is reacted with methanol to produce fatty acid methyl ester (FAME). Pure biodiesel can be used as a substitute for diesel but is often supplied as a blend. Vegetable oils may be obtained from crops including canola, soybean and sunflower, or oil palm.

A less common method for producing biofuel is hydrotreating to convert vegetable oil and tallow into a renewable diesel which can substitute directly for petro-diesel. A commercial example is the Neste Oil "NEXBTL" process. ${ }^{10}$

10 Aatola, H. et al., 2009, 'Hydrotreated Vegetable Oil (HVO) as a Renewable Diesel Fuel: Trade-off between NOx, particulate emission, and fuel consumption of a heavy duty engine', 1 SAE International Journal of Engines 1251. 


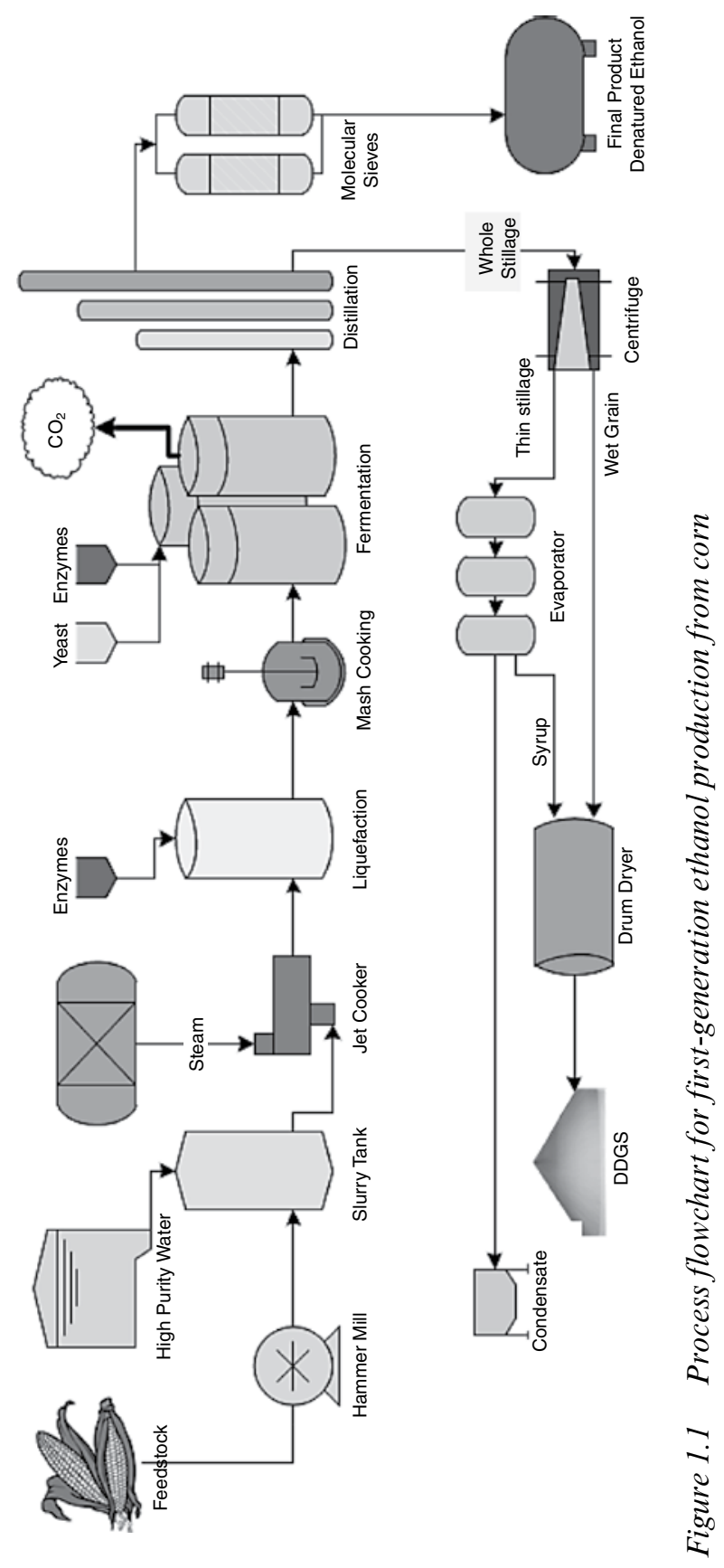




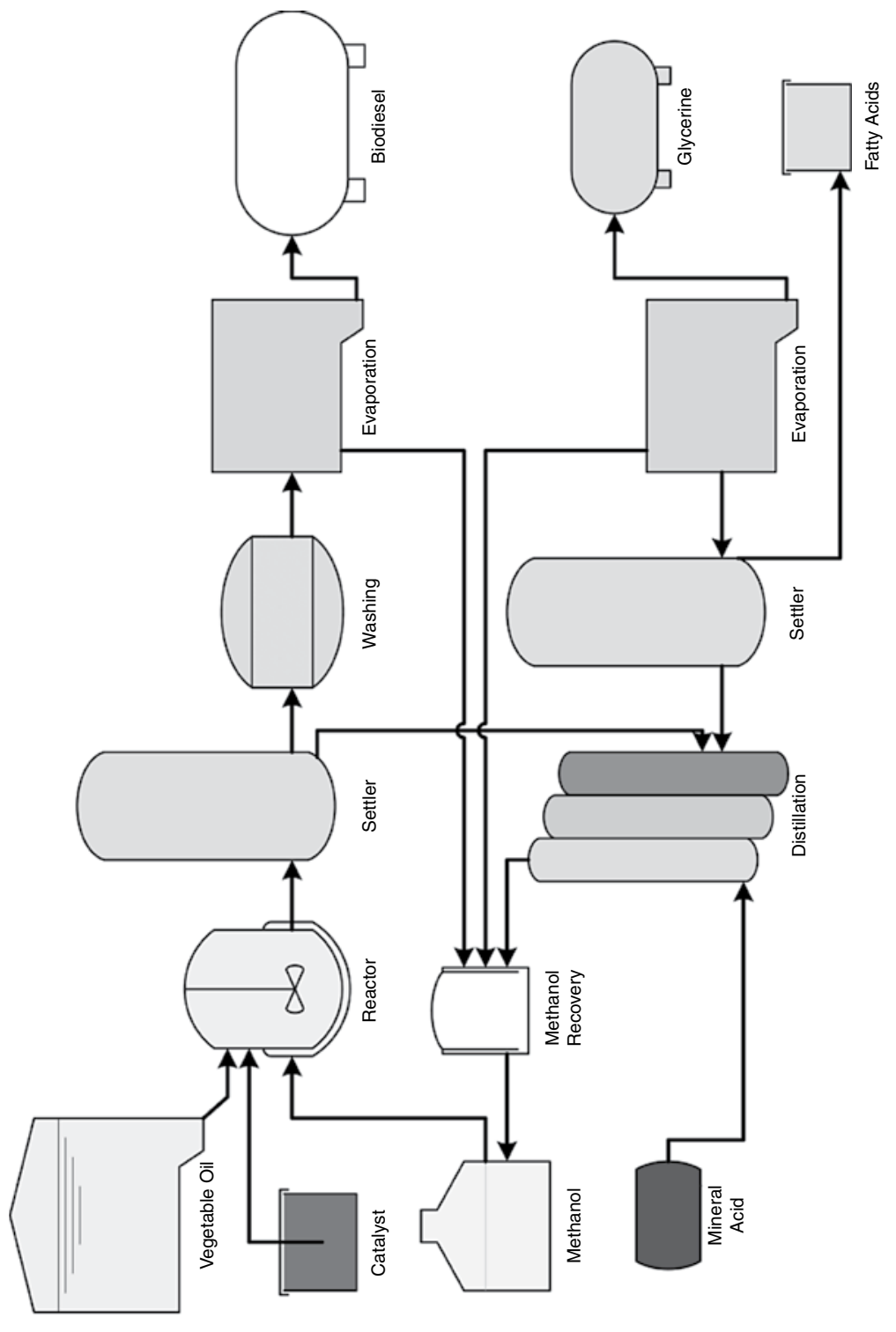

0
0
0
0
0
0
0
0
0
0
0
0
0
0
0
0
0
0
0
0
0
0
0
0
0
0
0
0
0
0
0
0
0
0
0
0
0
0
0 
Several other methods for converting biomass to liquid fuels have been developed. Pyrolysis involves heating biomass in an oxygen-limited environment to produce bio-oil, a solid char, and combustible gas. The crude bio-oil is upgraded through hydrogenation and further processing. ${ }^{11}$ Fast pyrolysis is being investigated as a route for the production of aviation fuel. ${ }^{12}$ Another method involves gasification of biomass to produce carbon monoxide, which is then converted to liquid fuel by the Fischer-Tropsch process, also known as biomass-to-liquid (BTL). While at least one commercial venture has been attempted, this process has yet to be commercialized.

Pyrolysis and gasification plants use woody biomass such as residues from harvest, milling, construction and could even use low-quality biomass sources such as municipal waste, though contaminants such as plastics and heavy metals create challenges for managing air emissions and disposal of residues.

There is much interest in producing biofuels from algae. Some algal species can produce high yields of lipids that could be readily converted to biodiesel. Other species grow rapidly and could be used as a feedstock for energy conversion technologies such as fermentation to ethanol, or hydrothermal processing into biocrude. Two alternative systems have been developed for algae production: cultivation in open raceway ponds is a low-cost method used commercially to produce algae for pharmaceuticals and food additives. The other system, known as a photobioreactor, is a closed system, often comprising plastic or glass tubing, through which water containing algae is pumped, and the alga are supplied with light, nutrients and $\mathrm{CO}_{2}$. This design maximizes interception of radiation, and avoids contamination with wild algal species. Pilot-scale photobioreactor systems have been demonstrated, but are not yet considered commercially viable. A major hurdle for algal biofuels is the energy requirement in "harvest", that is, separating the algae from the water in which they are grown. This may be achieved through various processes, including electroflocculation, flotation, centrifuging and solvent extraction ${ }^{13}-$ all steps which require energy, reducing the energy balance and net greenhouse gas (GHG) savings from the biofuel. Hydrothermal liquefaction may reduce

11 Mohan, D., C.U. Pittman and P.H. Steele, 2006, 'Pyrolysis of wood/biomass for bio-oil: a critical review', 20 Energy \& Fuels 848.

12 Vamvuka, D., 2011, 'Bio-oil, solid and gaseous biofuels from biomass pyrolysis processes - An overview', 35 International Journal of Energy Research 835.

13 Grierson, S., V. Strezov and J. Bengtsson, 2013, 'Life cycle assessment of a microalgae biomass cultivation, bio-oil extraction and pyrolysis processing regime', 2 Algal Research 299. 
the carbon footprint of algal biofuels as it gives high yield of biocrude and uses wet algal biomass. ${ }^{14}$

\subsection{ASSESSING THE ENVIRONMENTAL EFFECTS OF BIOFUELS}

Life cycle assessment (LCA) has been developed as a systematic method for characterizing the environmental effects of a product, process, organization or event, ${ }^{15}$ and is increasingly being used to inform policy design and in implementation of policy, including for biofuels. ${ }^{16}$ LCA was developed to simultaneously assess a wide range of environmental effects, from water quality to human toxicity, climate change impacts and air quality. LCA may also be applied to a single impact category. When it is applied to climate change it is known as carbon footprinting. ${ }^{17}$ Various guidelines and standards have been developed to encourage consistency in the application of LCA (for example ISO 14040, ${ }^{18}$ ISO14044, ${ }^{19}$ ILCD Handbook ${ }^{20}$ ). Standard characterization methods have been developed for expressing

14 Elliott, D.C. et al., 2013, 'Process development for hydrothermal liquefaction of algae feedstocks in a continuous-flow reactor', 2 Algal Research 445.

15 Klöpffer W. and B. Grahl, 2014, Life Cycle Assessment (LCA) (John Wiley \& Sons).

16 The USA Renewable Fuel Standard RFS2 http://www.epa.gov/OTAQ/ fuels/renewablefuels/ (last accessed on 27 October 2015) was informed by LCA analyses conducted using the Greenhouse Gases, Regulated Emissions, and Energy Use in Transportation (GREET) model developed by Argonne National Laboratory. The UK Renewable Transport Fuel Obligation https://www.gov. uk/renewable-transport-fuels-obligation (last accessed on 27 October 2015) uses a "carbon calculator" LCA-based tool https://www.gov.uk/government/publica tions/biofuels-carbon-calculator (last accessed on 27 October 2015) to calculate GHG emissions from biofuels; the Californian Low Carbon Fuel Standard program uses a modified version of the GREET model http://www.arb.ca.gov/ fuels/lcfs/ca-greet/ca-greet.htm to calculate GHG emissions of biofuels.

17 ISO, 2013, ISO/TS 14067:2013 Greenhouse gases - Carbon footprint of products - Requirements and guidelines for quantification and communication (International Organization for Standardization).

18 ISO, ISO 14040:2006 Environmental management - Life cycle assessmentPrinciples and framework, (International Organization for Standardization 2006).

19 ISO International Organization for Standardization, 2006, ISO 14044 Environmental management - Life cycle assessment - Principles and framework, (International Organization for Standardization).

20 Wolf, M.-A. et al., 2012, The International Reference Life Cycle Data System (ILCD) Handbook: Towards more sustainable production and consumption for a resource-efficient Europe (Publications Office). 
results consistently, facilitating comparison between products. Examples of common metrics and units are the use of global warming potential (GWP) to express climate change effects in terms of $\mathrm{CO}_{2}$ equivalent, and disability-adjusted life year (DALY) to express human toxicity effects. Specialist software and inventory databases are available to facilitate LCA calculations.

Many LCA studies have been conducted on biofuels, often focused only on GHG emissions but sometimes including energy balances. Very few have included other environmental impact categories such as biodiversity impacts. Studies have produced a wide range of results, for a number of reasons. First, results depend on features of the biofuel supply chain: the biomass production system, the properties of the feedstock, the conversion technology, and the fossil fuel displaced. Furthermore, LCA can deliver different results for apparently similar systems due to the influence of choices made by the researcher: system boundary of the analysis, which determines the processes included, method of allocating impacts between the biofuel and co-products, differences in background data, assumptions, models and emissions factors, exclusion or inclusion of indirect effects (for example indirect land use change (ILUC), non- $\mathrm{CO}_{2} \mathrm{GHG}$ emissions). To improve consistency between LCA studies, researchers, governments and industry are working together in many countries to develop publicly accessible national life cycle inventory databases that will contain average data for common product systems. This will enable researchers and industry to undertake LCA studies using consistent and accurate data for background processes, such as fertilizer manufacture, and thus reduce the resources required for LCA and improve the comparability between results.

Many published LCA studies for biofuel have used the attributional LCA modelling approach, ${ }^{21}$ in which the emissions along the supply chain are summed, and shared between the biofuel and other co-products on arbitrary bases such as relative energy content or monetary value of the co-products. This approach models the impact of the average unit of production, and is usually applied to existing supply chains. It is generally focused on a particular product, as a case study or to inform product labelling or compliance assessment, for a specific situation. In using these results to estimate the effects of expansion of the biofuel industry it is commonly assumed that $1 \mathrm{MJ}$ of biofuel energy will displace $1 \mathrm{MJ}$ of fossil fuel. However, this assumption does not acknowledge the impacts that market forces may play, indirectly influencing the outcome through the impact on

21 Curran, M.A., M. Mann and G. Norris, 2005, 'The international workshop on electricity data for life cycle inventories', 13 Journal of Cleaner Production 853. 
demand for fossil fuels as their prices change due to the increase in supply of biofuels. ${ }^{22}$ It has been estimated that because of this "rebound effect", the displacement factor varies from 0.25 to 1.6 , and is usually less than $1 .{ }^{23}$ It has been suggested ${ }^{24}$ that the attributional approach does not give accurate estimates of the full climate impact of a large-scale change in biofuel supply and that, to inform the development of biofuel policy, a consequential modelling approach ${ }^{25}$ is required. This considers the impacts on the agricultural or forestry sector supplying the biomass, ${ }^{26}$ on the energy sector, and indirect land use impacts, which requires economic approaches, such as computable general equilibrium (CGE) or partial equilibrium (CPE) modelling. Bio-geophysical modelling is also needed to understand the environmental impacts of these changes in land use and land management, and impacts of emissions to air and water from conversion and combustion stages. Such analyses should also consider the anticipated effects of climate change. This is likely to alter crop growth rates and requirements for irrigation, and likely to increase yield variability and production costs. Ideally, modelling should consider spatial variation across the landscape, and incorporate hydrological impacts. Integrated assessment models (IAM) that include both bio-geophysical and economic processes are used by policy research groups to assess mitigation options for long-term climate stabilization. ${ }^{27}$

22 Rajagopal, D., G. Hochman and D. Zilberman, 2011, 'Indirect fuel use change (IFUC) and the lifecycle environmental impact of biofuel policies', 39 Energy Policy 228.

23 Hochman, G., D. Rajagopal and D. Zilberman, 2010, 'The effect of biofuels on crude oil markets', 13 AbBioForum 2; Drabik, D. and H. De Gorter, 2011, 'Biofuel policies and carbon leakage', 14 AgBioForum 2; Chen, X. and M. Khanna, 2012, 'The market-mediated effects of low carbon fuel policies', 15 AgBioForum 11; Rajagopal, D. and R.J. Plevin, 2013, 'Implications of marketmediated emissions and uncertainty for biofuel policies', 56 Energy Policy 75; Rajagopal, D., 2014, 'Consequential life cycle assessment of policy vulnerability to price effects', 18 Journal of Industrial Ecology 164.

24 Plevin, R.J., M.A. Delucchi and F. Creutzig, 2014, 'Using attributional life cycle assessment to estimate climate-change mitigation benefits misleads policy makers', 18 Journal of Industrial Ecology 73; Brandão, M. et al., 2014, 'The use of life cycle assessment in the support of robust (climate) policy making: comment on "using attributional life cycle assessment to estimate climate-change mitigation", 18 Journal of Industrial Ecology 461.

25 Supra, n. 21.

26 Miner, R.A. et al., 2014, 'Forest carbon accounting considerations in US bioenergy policy', 112 Journal of Forestry 591.

27 Krey, V., 2014, 'Global energy-climate scenarios and models: a review', Wiley Interdisciplinary Reviews: Energy and Environment n/a. 


\subsection{LAND USE FOR BIOFUELS}

Although the land area currently devoted to biofuel crops is less than $1 \%$ of agricultural land globally, ${ }^{28}$ there are environmental concerns about biofuels related to land use for growing feedstocks. Critics assert that biofuel crops cause deforestation, emitting greenhouse gases and threatening endangered wildlife. Concerns are also raised over socio-economic issues such as displacement of smallholders and implications for food security. Here we discuss land use issues, and approaches to minimizing negative effects of land requirement for biofuels.

While the current area of bioenergy crops is small compared with the overall agricultural land area, expansion of biofuels may displace production of food, animal feed, fibre or wood products, leading to a risk of indirect land use change. Unchanged demand for the displaced product may lead to deforestation elsewhere. The overall requirement for land is estimated to increase, due to requirement for additional cropland and grazing land, biofuel crops, urban expansion, expansion of industrial forestry, expansion of protected areas, and declining productivity due to land degradation, all resulting in pressure for deforestation. ${ }^{29}$

Indirect land use change (ILUC) has been claimed to reduce the climate change benefits of biofuels, ${ }^{30}$ and to cause loss of biodiversity, and social dis-benefits through threats to food security ${ }^{31}$ and "displacement of poor rural communities". ${ }^{32}$ For example, it is asserted that using corn for ethanol in the USA displaces animal feed production, leading to expansion of soybean cultivation onto pastureland in Brazil to provide alternative animal feed, in turn causing deforestation in the Amazon to provide grazing land. ${ }^{33}$ However, the scale of biofuel-induced ILUC is contested.

Estimates of ILUC are commonly based on economic models, such

28 Edenhofer, O. et al., 2011 Renewable Energy Sources and Climate Change Mitigation: Special report of the intergovernmental panel on climate change (Cambridge University Press) 270.

29 Lambin, E.F. and P. Meyfroidt, 2011, 'Global land use change, economic globalization, and the looming land scarcity', Proceedings of the National Academy of Sciences 3465.

30 Searchinger, T. et al., 2008, 'Use of US croplands for biofuels increases greenhouse gases through emissions from land-use change', 319 Science 1238.

31 Pimentel, D. et al., 2009, 'Food versus biofuels: environmental and economic costs', 37 Human Ecology 1.

32 De Schutter, O., 2011, 'How not to think of land-grabbing: three critiques of large-scale investments in farmland', 38 Journal of Peasant Studies 249.

33 Arima, E.Y. et al., 2011, 'Statistical confirmation of indirect land use change in the Brazilian Amazon', 6 Environmental Research Letters 024010. 
as computable general equilibrium models (for example Global Trade Analysis Project, GTAP; Modelling International Relationships in Applied General Equilibrium, MIRAGE) which apply equations describing price elasticities of supply and demand to estimate response of the economy to changes in policy. These models, of necessity, apply simplified relationships and assumptions about market responses to changes in supply and demand. They have been criticized for their uncertainty, and for failure to reflect reality. Estimates of ILUC due to biofuel expansion have been demonstrated to be inconsistent with measured rates of deforestation. ${ }^{34}$ In part, this inconsistency is due to the failure of the models to adequately account for management responses. For example, Langeveld et al. ${ }^{35}$ have demonstrated that increased intensity of production through multiple cropping, due to market forces, has largely compensated for expansion of area occupied by biofuels in the major biofuel-producing countries. On the other hand, increasing raw material demand for food and feed may increase the competition with raw materials used for biofuels in the future.

\subsection{MINIMIZING ILUC}

A range of strategies can be used to supply biofuel feedstocks while minimizing the risk of ILUC. First, use of biomass sources that are wastes, such as used cooking oil and secondary processing residues (for example sawdust, nut shells), and construction and demolition waste (lumber offcuts and end-of-life wood products), presents a low risk of ILUC. However, only small quantities of these feedstocks are produced, relative to the quantity of biomass required to satisfy growing demands for transport fuels, so their contribution to biofuel production will be small. $^{36}$

Second, in relation to first-generation biofuels, increasing intensity of

34 Strapasson, A.B. et al., 2012, 'Agro-ecological zoning and biofuels: the Brazilian experience and the potential application in Africa', in Johnson, F.X. and Seebaluck., V., Bioenergy for Sustainable Development And International Competitiveness - The role of sugar cane in Africa, Routledge, London 48; INPE, 'Projeto PRODES: Monitoramento da Floresta Amazônica por Satélite. Brazilian National Institute for Space Research' (2014) <http://www.obt.inpe.br/prodes/ index.php.> accessed 10 September 2014 (last accessed on 27 October 2015).

35 Langeveld, J.W.A. et al., 2014, 'Analyzing the effect of biofuel expansion on land use in major producing countries: evidence of increased multiple cropping', 8 Biofuels, Bioproducts and Biorefining 49.

36 Creutzig, F. et al., 2014, 'Bioenergy and climate change mitigation: an assessment', 7 GCB Bioenergy 916. 
production on currently cropped areas can reduce land requirements. If the yield can be increased per unit area, such as through improved varieties, increased mechanization, irrigation, use of fertilizer, and shorter fallow periods, less land is required for biofuel feedstock production. For example, the 100 million tonne increase in use of corn for ethanol in the USA in the period 2000 to 2010 was matched by a 100 million tonne increase in corn harvested. This was largely a result of increased yield per hectare, and only a small increase in land area devoted to corn. ${ }^{37}$ Intensification may cause additional pressures on soil and water resources, and greater risk of off-site impacts, as discussed below; nevertheless, there is potential for sustainable intensification to reduce the competition between food and energy production. ${ }^{38}$

Third, biofuel crops may be cultivated on marginal or "unused" land. Jatropha (Jatropha curcas), a shrub with oil-rich seeds, has been marketed as a "miracle crop", able to be grown on saline soils in arid regions. The reality is that while Jatropha may survive in low rainfall, low fertility or saline conditions, its productivity is low. ${ }^{39}$ Similarly, Arundo donax has been promoted for its potentially high biomass growth rate and ability to withstand poor conditions, but high growth rates are achieved only on fertile soils in favourable environments. Nevertheless, there are examples of successful establishment of biofuel crops on marginal lands. In Indonesia, oil palm has been planted into infertile Imperata cylindrica grasslands, where it has not only yielded well but also improved soil fertility. ${ }^{40}$ The concept of "unused land" is often inaccurate: in many developing countries the poor occupy public and communal land which is considered "idle"; converting such land to biofuel crops displaces local land users, risking indirect land use change, in addition to negative social impacts. In addition, if "unused land" (for example abandoned agricultural land) would sequester carbon, for example by regenerating to a forest, taking the land into cultivation leads to foregone carbon sequestration.

A fourth strategy to minimize the risk of indirect land use change is the use of residues from cropping or forestry systems, such as corn stover,

37 Wallington, T.J. et al., 2012, 'Corn ethanol production, food exports, and indirect land use change', 46 Environmental Science \& Technology 6379.

38 Godfray, H.C.J. et al., 2010, 'Food security: the challenge of feeding 9 billion people', 327 Science 812 .

39 Jongschaap, R.E.E. et al., 2007, Claims and Facts on Jatropha curcas L. (Plant Research International B.V., Wageningen).

40 Wicke, B. et al., 2011, 'Exploring land use changes and the role of palm oil production in Indonesia and Malaysia', 28 Land Use Policy 193. 
wheat straw, sugar cane trash, forest slash. These lignocellulosic biomass types are usually left to decay in the field. As production of biomass is not the main driver of these land use systems, removal of residues for biofuel production will not directly affect land use. However, residue removal will increase nutrient export, necessitating increased fertilizer application. It may increase susceptibility to erosion and cause decline in soil organic matter content, so management practices should be developed to maintain productivity. The potential supply of residues is estimated at between 40 to $125 \mathrm{EJ} / \mathrm{yr}$, corresponding to some $10-25 \%$ of the global primary energy supply in $2008 .^{41}$

A fifth strategy could be the use of purpose-grown lignocellulosic crops to produce second-generation biofuels. This is expected to reduce the land area required for biofuel production, due to the larger mass of feedstock harvested per hectare. The yield of lignocellulosic crops used for Fischer-Tropsch diesel is estimated at around $190 \mathrm{GJ} /$ ha, compared with $60 \mathrm{GJ} /$ ha for corn-based ethanol. ${ }^{42}$

Integrating biomass production into existing agricultural systems is a sixth strategy to produce feedstock that minimizes land requirements. Such integrated systems could include agroforestry and alley cropping systems combining tree and annual crops, preferably with complementary resource requirements so that the combined system achieves greater yield. Synergistic options include shelter-belts of woody plants that provide shade and windbreaks to livestock; legume tree belts that provide nitrogen to the annual crop; and hedgerows established around pasture and annual crop fields that provide habitat for beneficial organisms that control pests. An example is mallee eucalypts planted in strips across wheat fields in Western Australia, which can lower saline water tables, enhancing wheat yields while producing biomass for bioenergy. ${ }^{43}$

A seventh strategy to minimize indirect land use change is to use the co-products of biofuel production to substitute for displaced agricultural products. For example, the dried distillers grains co-produced with ethanol are a valuable high-protein animal feed, as are the residues from biodiesel production based on soy and canola. Thus, the impact of the diversion of feed to ethanol production is partly offset by the use

41 IEA 2015 http://www.iea.org/Sankey/index.html (last accessed on 27 October 2015),

42 IEA $2011 \mathrm{http} / /$ www.iea.org/publications/freepublications/publication/ Biofuels_Roadmap_WEB.pdf (last accessed on 27 October 2015).

43 Davis, S.C. et al., 2013, 'Management swing potential for bioenergy crops', 5 GCB Bioenergy 623. 
of these residues as feed. The estimated area of ILUC is reduced when co-products are taken into consideration. Langeveld et al. ${ }^{44}$ assessed the impacts of the biofuel programmes on the major biofuel-producing countries and found that, between 2000 and 2010, expanded biofuel production accounted for an additional 25 Mha of cropland, but when co-products (primarily animal feeds) were included the net land demand dropped to 14 Mha.

The impact of land use for biofuels is thus largely determined by the extent to which each of these strategies (use of lignocellulosic crops, primary and secondary residues, integrated production systems, intensification, use of marginal land) is employed to produce biofuel feedstock. The above strategies can be encouraged through legislated incentives such as the EU REDD+ and the USA RFS2 mandate for cellulosic biofuels. Nevertheless, as described in other chapters, these measures do not necessarily produce the desired outcomes. Legislative controls over land clearing may be needed to indirectly promote more sustainable methods.

\subsection{CLIMATE CHANGE EFFECTS}

The climate change mitigation value of biofuels has been increasingly questioned over recent years, since policies were enacted to promote biofuels for their anticipated climate change benefits.

To deliver a climate change benefit the biofuel system must have lower emissions, from a whole-system perspective, than the fossil fuel system it replaces. Early critics of the biofuel industry ${ }^{45}$ declared that the fossil energy used in cultivation and processing of feedstocks to produce ethanol and biodiesel was greater than the energy of the biofuel produced. Counterclaims criticized these studies for use of out-dated and biased data. ${ }^{46}$ The next wave of criticism pointed the finger at indirect land use change (see above). This was followed by claims that nitrous oxide emissions resulting directly and indirectly from use of $\mathrm{N}$ fertilizer in biofuel

\footnotetext{
44 Supra, n. 35.

45 Pimentel, D. and T. Patzek, 2007, 'Ethanol production: Energy and economic issues related to U.S. and Brazilian sugarcane', 16 Natural Resources Research 235; Pimentel, D. and T.W. Patzek, 2005, 'Ethanol production using corn, switchgrass, and wood; biodiesel production using soybean and sunflower', 14 Natural Resources Research 65.

46 Farrell, A.E. et al., 2006, 'Ethanol can contribute to energy and environmental goals', 311 Science 506.
} 
production could negate the mitigation benefits of biofuel. ${ }^{47}$ Recently, Liska et al ${ }^{48}$ have claimed that soil carbon loss in the cultivation of corn negates the climate change benefits of ethanol from corn stover; the study has been criticized for use of inaccurate estimates of the amount of stubble removed in conventional systems. ${ }^{49}$ This saga of criticisms and counterclaims points to the important factors that determine the climate change impacts of biofuel systems: fossil fuel use along the supply chain, biomass production and conversion; emissions due to carbon stock change in vegetation and soil, both at the site of biomass production and through indirect land use change; non- $\mathrm{CO}_{2}$ greenhouse gas emissions from biomass production; and the extent to which each unit of biofuel displaces fossil fuel.

The carbon footprint of biofuels is closely related to the energy balance. Because of higher yields and lower fertilizer requirements, the energy yield ratio, or "energy return on investment", of sugarcane-based ethanol is four to six times greater than the energy yield ratio of corn-based ethanol. ${ }^{50}$ Supply chain emissions, excluding land use change effects, range from 2 to $69 \mathrm{~kg} \mathrm{CO}_{2}$-eq/GJ for ethanol and 20 to $49 \mathrm{~kg} \mathrm{CO}_{2}$-eq/GJ for biodiesel. ${ }^{51}$ Emissions tend to be higher for first-generation annual crops, which generally have high inputs of fertilizer and fuel, and lower for lignocellulosic feedstocks. This is despite the fact that the latter require greater energy and chemical inputs in pre-treatment to break down complex molecules, and large quantities of enzymes, which have a substantial carbon footprint. ${ }^{52}$ Improvements in conversion technologies, such as enzyme

47 Crutzen, P.J. et al., 2007, 'N2O release from agro-biofuel production negates global warming reduction by replacing fossil fuels', 7 Atmos Chem Phys Discuss 11191.

48 Liska, A.J. et al., 2014, 'Biofuels from crop residue can reduce soil carbon and increase CO2 emissions', 4 Nature Clim Change 398.

49 Sheehan, J.J. et al., 2014, 'CO2 emissions from crop residue-derived biofuels', 4 Nature Clim Change 932.

50 von Blottnitz, H. and M.A. Curran, 2007, 'A review of assessments conducted on bio-ethanol as a transportation fuel from a net energy, greenhouse gas, and environmental life cycle perspective', 15 Journal of Cleaner Production 607; Macedo, I.C., J.E.A. Seabra and J.E.A.R. Silva, 2008, 'Green house gases emissions in the production and use of ethanol from sugarcane in Brazil: The 2005/2006 averages and a prediction for 2020', 32 Biomass and Bioenergy 582; Shapouri, H. et al., 2010, 2008 Energy Balance for the Corn-Ethanol Industry, (Agricultural Economic Report Number 846).

51 Supra, n. 48, p. 65, Table TS-6.

52 MacLean, H.L. and S. Spatari, 2009, 'The contribution of enzymes and process chemicals to the life cycle of ethanol', 4 Environmental Research Letters 014001; Slade, R., A. Bauen and N. Shah, 2009, 'The greenhouse 
recycling, improved enzyme efficiency, and system integration may further reduce the supply chain emissions for lignocellulosic feedstocks. ${ }^{53}$

Decline in carbon stock in soil, such as where intensive cropping with residue removal replaces less intensive agricultural systems could reduce the climate change benefits of bioenergy systems. ${ }^{54}$ In most forestry systems removal of residues leads to small losses in soil carbon, compared with the benefits of avoiding fossil fuel emissions. ${ }^{55}$ However, clearing and draining tropical forested peatlands to grow oil palm leads to large losses in biomass and soil carbon. These may take many decades to recoup through displaced fossil fuel emissions, ${ }^{56}$ despite the high productivity of oil palm. On the other hand, planting biofuel crops in marginal and degraded lands can increase carbon stocks in biomass and soil (for example oil palm on imperata ${ }^{57}$ ).

Loss of carbon stocks in biomass and soil through indirect land use change also reduces the mitigation benefits of biofuels. The scale of ILUC is unclear (see discussion above). Impacts may range from over 450 to $-80 \mathrm{~g} \mathrm{CO}_{2}$-eq/MJ for biodiesel and from 270 to $-90 \mathrm{~g} \mathrm{CO}_{2}$-eq/MJ for ethanol supply chains. ${ }^{58}$

Nitrogen is the most abundant nutrient in plant tissue, and is exported in significant quantities when biomass is harvested. Nitrogen removed in biomass must be replaced through chemical or organic fertilizers. This leads to GHG emissions through several routes, notably: manufacture of nitrogen fertilizer which is a GHG-intensive process because of high energy requirement and use of natural gas as a hydrogen source in the conversion

gas emissions performance of cellulosic ethanol supply chains in Europe', 2 Biotechnol Biofuels 1.

53 Qi, B. et al., 2012, 'Application of ultrafiltration and nanofiltration for recycling cellulase and concentrating glucose from enzymatic hydrolyzate of steam exploded wheat straw', 104 Bioresource technology 466.

54 Supra, n. 48.

55 Cowie, A.L., P. Smith and D. Johnson, 2006, 'Does soil carbon loss in biomass production systems negate the greenhouse benefits of bioenergy?' 11 Mitigation and Adaptation Strategies for Global Change 979.

56 Fargione, J. et al., 2008, 'Land clearing and the biofuel carbon debt', 319 Science 1235.

57 Ibid.; Gibbs, H.K. et al., 2008, 'Carbon payback times for crop-based biofuel expansion in the tropics: the effects of changing yield and technology', 3 Environmental Research Letters 034001.

58 Supra, n. 7. IPCC, 2014, 'Summary for Policymakers', in: Climate Change 2014: Mitigation of Climate Change. Contribution of Working Group III to the Fifth Assessment Report of the Intergovernmental Panel on Climate Change (O. Edenhofer and others (eds), Cambridge University Press, Cambridge, United Kingdom and New York, NY, USA). 
of nitrogen gas to ammonia, releasing 2-10 $\mathrm{g} \mathrm{CO}_{2} \mathrm{e}\left(\mathrm{CO}_{2}\right.$ equivalents) per $\mathrm{g}$ fertilizer-N; ${ }^{99}$ and application of $\mathrm{N}$ fertilizers, whether organic or chemical, which leads to release of nitrous oxide, particularly in moist environments that favour denitrification. ${ }^{60}$ While some studies ${ }^{61}$ have claimed that nitrous oxide emissions resulting directly and indirectly from use of $\mathrm{N}$ fertilizers in biomass production could negate the climate benefits of biofuels, others ${ }^{62}$ criticized Crutzen and colleagues for overestimating indirect nitrous oxide emissions. Nevertheless, nitrous oxide emissions can make a significant contribution to the GHG balance of biofuels. ${ }^{63}$

Also of relevance to the climate impact is the extent to which biofuel supplements rather than displaces fossil fuels, due to the "rebound effect" which arises because the increased supply of biofuel reduces the price of fossil fuels and thus increases their consumption. In relation to electricity generation, estimates of rebound vary widely, suggesting that a unit of renewable energy may displace between 0 and 1.6 units of fossilfuel-generated electricity in different situations, with the factor generally less than one. ${ }^{64}$ The large range is mainly due to uncertainties in the policy context and assumptions about fuel demand and supply elasticity assumptions.

Besides effects on emissions and removals of greenhouse gases, cultivation of biomass crops can influence climate through effects on other climate forcing processes. The albedo of a surface determines the extent to which it reflects or absorbs incident radiation. Harvest of forests in high latitudes or altitudes that receive snowfall can increase albedo, reducing global warming because the formerly dark surface of the forest will now be white, reflecting the radiation. ${ }^{65}$ In some circumstances this

59 Wood, S. and A. Cowie, 2004, 'A review of greenhouse gas emission factors for fertilizer production', IEA Bioenergy Task 38.

60 Mosier, A. et al., 1998, 'Closing the global N2O budget: nitrous oxide emissions through the agricultural nitrogen cycle', 11 Nutrient Cycling in Agroecosystems 225.

61 Supra, n. 47; Mosier, A. et al., 2009, 'Nitrous oxide's impact on net greenhouse gas savings from biofuels: life-cycle analysis comparison', 52 International Journal of Biotechnology 60.

62 Berndes, G., N. Bird and A. Cowie, 2011, Bioenergy, Land Use Change and Climate Change Mitigation - Technical report (IEA Bioenergy ExCo).

63 Smeets, E.M.W. et al., 2009, 'Contribution of N2O to the greenhouse gas balance of first-generation biofuels', 15 Global Change Biology 1.

64 York, R., 2012, 'Do alternative energy sources displace fossil fuels?', 2 Nature Climate Change 441; Supra, n. 22.

65 Bright, R.M., R. Astrup and A.H. Strømman, 2013, 'Empirical models of monthly and annual albedo in managed boreal forests of interior Norway', 120 Climatic Change 183. 
effect is substantial, even counteracting negative impacts of a reduction in forest carbon stock due to biomass harvest. ${ }^{66}$ Similarly, in the Brazilian Cerrado, changes in albedo and evapotranspiration ${ }^{67}$ associated with the conversion of crop and pasture land to sugarcane led to localized cooling due largely to the cooling effect of evaporation, enhancing the climate mitigation benefit of biofuels. ${ }^{6}$ In contrast, where evergreen biomass crops are planted into snow-covered or arid land with high albedo, the land surface albedo may be decreased, reducing the mitigation benefits. ${ }^{69}$ Thus, changes in surface albedo may have a positive or negative influence, depending on the land use or land management change, and the location. The issue becomes more difficult when the role of forests in cloud formation is considered. ${ }^{70}$

\subsection{EFFECTS ON SOIL}

Just as the feedstock source determines the climate effects and the risk of ILUC, the feedstock also determines the effect on soil. Impacts on soil are most likely to arise in biofuel systems using purpose-grown biofuel crops, or feedstocks based on crop and forest residues. The impacts derive from removal of biomass and cultivation for crop establishment.

Biofuel systems that involve removal of a substantial proportion of the biomass grown (for example grass crops such as miscanthus and switchgrass, short rotation poplar and willow, cereal straw or forestry slash) may suffer loss of soil organic matter content through reduction in biomass inputs to soil. ${ }^{71}$ Biofuel systems that involve regular cultivation, such as for annual crops, and/or removal of biomass residues, are vulnerable to soil erosion. This can further reduce soil organic matter (SOM) content, as SOM is concentrated in the topsoil.

66 Bright, R.M., A.H. Strømman and G.P. Peters, 2011, 'Radiative forcing impacts of boreal forest biofuels: a scenario study for Norway in light of albedo', 45 Environmental Science and Technology 7570.

67 Evapotranspiration is the transfer of water from soil to atmosphere through evaporation from the soil surface and transpiration by plants.

68 Loarie, S.R. et al., 2011, 'Direct impacts on local climate of sugar-cane expansion in Brazil', 1 Nature Climate Change 105.

69 Schwaiger, H.P. and D.N. Bird, 2010, 'Integration of albedo effects caused by land use change into the climate balance: Should we still account in greenhouse gas units?', 260 Forest Ecology and Management 278.

70 Bonan, G.B., 2008, 'Forests and climate change: forcings, feedbacks, and the climate benefits of forests', 320 Science 1444.

71 Supra, n. 55. 
Cultivation may also stimulate loss of SOM through increased rates of decomposition. ${ }^{72}$ Soil organic matter is fundamental to the chemical, physical and biological health of soils, retaining water and nutrients, aiding aeration, root penetration, water infiltration and nutrient cycling. ${ }^{73}$ It is critical to maintaining productivity, so loss of SOM is a major challenge to the sustainability of biofuel production systems. ${ }^{74}$ Conversion from forest or grassland to biofuel crops is likely to cause loss of organic matter. ${ }^{75}$ Where forested tropical peatland soils have been drained and cultivated for oil palm, large losses of soil organic matter have been recorded, ${ }^{76}$ often accompanied by dramatic subsidence in ground level. ${ }^{77}$

Where existing agricultural land is used for biofuel crops, this may lead to land clearing elsewhere (see ILUC, above). In this case, the effects of land clearing on soil described above will occur at the site of land use change, external to the biofuel crop location.

Removal of biomass for biofuel exports nutrients from the site, in proportion to their concentration in biomass. Thus, removal of green foliage and bark, which are particularly high in N, P, K and Ca, presents a greater risk of nutrient depletion than where only stem-wood is removed. The loss of nutrients will lead to loss of soil fertility in the long term where biomass is continually removed ${ }^{78}$ unless these nutrients are replaced by legume crops or chemical or organic fertilizers. Harvest of biomass can be scheduled to reduce the export of nutrients, for example by harvesting after leaf

72 Murphy, B.W. et al., 2011, 'Tillage and crop stubble management and soil health in a changing climate', in Soil Health and Climate Change (Springer).

73 Tisdall, J. and J.M. Oades, 1982, 'Organic matter and water-stable aggregates in soils', 33 Journal of Soil Science 141.

74 George, B.H. and A.L. Cowie, 2011, 'Bioenergy systems, soil health and climate change', in Singh, B., A.L. Cowie and K.Y. Chan (eds), Soil Health and Climate Change (Vol 29 edn, Springer) <http://www.springer.com/life+sciences/ agriculture/book/978-3-642-20255-1 http://link.springer.com/chapter/10.1007\%2 F978-3-642-20256-8_16> (last accessed on 27 October 2015).

75 Guo, L.B. and R.M. Gifford, 2002, 'Soil carbon stocks and land use change: a meta analysis', 8 Global Change Biology 345.

76 Wicke, B. et al., 2008, 'Different palm oil production systems for energy purposes and their greenhouse gas implications', 32 Biomass and Bioenergy 1322.

77 Hooijer, A. et al.., 'Subsidence and carbon loss in drained tropical peatlands' 9 Biogeosciences 1053.

78 Blanco-Canqui, H., 2010, 'Energy crops and their implications on soil and environment', 102 Agronomy Journal 403; Dickmann, D., 2006, 'Silviculture and biology of short-rotation woody crops in temperate regions: Then and now', 30 Biomass and Bioenergy 696. 
fall in deciduous species, or windrowing ${ }^{79}$ cut stems in the field until the leaves and bark drop.

Some biofuel production systems can have positive effects on soil. Perennial lignocellulosic biofuel crops can improve soil quality compared with annual sugar and starch crops, due to less frequent cultivation. Soil carbon levels have been found to increase under switchgrass, for example, ${ }^{80}$ and oil palm planted on marginal land. ${ }^{81}$ Soil erosion will also be reduced and soil structure improved in perennial crops compared with annuals. Leguminous biofuel crops (for example soybean) add nitrogen to the soil. Deep-rooted perennial species can lower saline water tables, and thus reduce dryland salinity. ${ }^{82}$

Potential negative effects of biofuels on soil can be minimized through sustainable land management practices that seek to maintain or improve soil health, such as retention of residues as mulch to protect the soil; contour ploughing to minimize erosion; application of organic amendments to enhance soil organic matter content and nutrient cycling; and selection of harvest time to minimize nutrient export.

\subsection{EFFECTS ON WATER RESOURCES}

Increasing biofuel production is likely to impact both the quantity and quality of available water resources. Biofuel supply chains often have higher water use than the comparable fossil fuel systems, though there can be both positive and negative impacts. ${ }^{83}$

The most significant effects on the hydrological cycle from biofuels are expected to occur at the feedstock production stage. When traditional field crops are used, particularly where these are irrigated, the strain on water availability could be substantial at the local and regional level, ${ }^{84}$

79 Windrowing is a procedure in which plant tops or branches are cut and laid out in rows across a field, to dry.

80 Follett, R.F. et al., 2012, 'Soil carbon sequestration by switchgrass and notill maize grown for bioenergy', 5 BioEnergy Research 866.

81 Supra, n. 74.

82 Robinson, N., R.J. Harper and K.R.J. Smettem, 'Soil water depletion by Eucalyptus spp. integrated into dryland agricultural systems', 286 Plant and Soil 141.

$83 \mathrm{Wu}, \mathrm{M}$. et al., 2009, 'Water consumption in the production of ethanol and petroleum gasoline', 44 Environmental Management 981; Fingerman, K.R. et al., 2010, 'Accounting for the water impacts of ethanol production', 5 Environmental Research Letters 014020.

84 Berndes, G., 2002, 'Bioenergy and water - the implications of large-scale bioenergy production for water use and supply', 12 Global Environmental Change 253. 
though possibly of lesser concern at the global level. ${ }^{85}$ It is expected that the replacement of first-generation with second-generation/lignocellulosic biofuel crops (that generally do not require irrigation and are deep-rooted) will reduce water use.

Bioenergy crops may be sited strategically in the landscape to improve hydrology. For example, the Western Australian wheatbelt has suffered from raising saline water tables, and deep-rooted mallee eucalypts planted for bioenergy have been effective in lowering the water table. ${ }^{86}$

Biofuel facilities use process water in the conversion of biomass to fuel. Some facilities use water in large quantities for washing plants and seeds, and for evaporative cooling. The volume of water consumed in processing is small compared with the volume of water required for growing the feedstock. ${ }^{87}$ However, as Schnoor et al ${ }^{88}$ point out, water use in fuel processing is concentrated into a small area, and can have substantial impacts for local water resources.

Intensification of production of first-generation biofuel crops is likely to exacerbate existing environmental water quality problems, such as nutrient, pesticide and other agrochemical loadings in farm runoff and groundwater flows. In some regions, increased sediment runoff due to increased cropping area and intensity is the most important environmental effect. For example, the upper Mississippi River in the USA experiences high sedimentation rates, which have consequences for aquatic ecosystems and riverine recreation and transport. ${ }^{89}$

Schnoor et al. ${ }^{90}$ state that "[e]xcess nitrogen in the Mississippi River system is known to be a major cause of the oxygen-starved 'dead zone' in the Gulf of Mexico". They also note that there are concerns that increased biomass production may have serious consequences for coastal and offshore waters.

Biofuel production plants may generate waste streams from the production processes. These waste streams, such as reverse osmosis brine effluent, cooling tower salts and waste heat, may be discharged into water bodies along with wastewater with high biological oxygen demand (BOD). This can cause environmental contamination and biodiversity impacts.

85 De Fraiture, C., M. Giordano and Y. Liao, 2008, 'Biofuels and implications for agricultural water use: blue impacts of green energy', 10 Water Policy 67.

86 Supra, n. 82.

87 Supra, n. 84.

88 Schnoor, J.L. et al., 2008, 'Water implications of biofuels production in the United States', National Academy of Sciences, Washington DC, USA.

89 Ibid., p. 30.

90 Ibid. 
There are indications that biofuels can have positive effects on water resources. For example, planting switchgrass, which has low fertilizer requirements, around the perimeter of cropping areas and along waterways can reduce the nitrate contamination of groundwater. ${ }^{91}$ Use of ethanol blend fuels avoids the need for the addition of methyl tert-butyl ether (MTBE), an additive in conventional fuels. This is being phased out in the USA because of contamination of groundwater. ${ }^{92}$ In addition, perennial crops can conserve soil outside the growing season of annual crops by diminishing the erosion from precipitation and runoff. ${ }^{93}$

Spills and leaks of biofuels are likely to have less environmental impact than fossil fuels because of their readily biodegradable nature. However, biodiesel and ethanol spills into water courses can lead to downstream fish kills due to the reduction of dissolved oxygen levels associated with the rapid biodegradation. Responses to biofuel spills may need a different approach to the procedures established for petro-chemical spills.

The use of wastes such as cooking oil for biofuel production systems can have a positive impact on water resources. Until recent years, these cooking oils were mostly disposed of in landfills, where they could leach into groundwater. Recycling waste materials into fuel keeps them out of the waste stream, and thereby may reduce groundwater contamination.

Tallow, a by-product of meat production, can also be used as a biodiesel feedstock. Runoff from cattle feedlots may lead to groundwater contamination. Therefore, biodiesel made from tallow as a by-product of feedlot meat production should be apportioned a share of responsibility for some of the feedlot groundwater contamination. ${ }^{94}$

\subsection{AIR QUALITY EFFECTS}

As discussed in other sections, it is expected that the increased adoption of biofuel systems will significantly reduce GHG emissions. Aside from the GHG impacts of biofuels, there are other air quality issues associated

91 Bransby, D.I., S.B. McLaughlin and D.J. Parrish, 1998, 'A review of carbon and nitrogen balances in switchgrass grown for energy', 14 Biomass and Bioenergy 379.

www.epa.gov/mtbe/faq.htm (last accessed on 27 October 2015).

Berndes, G., 2008, 'Future biomass energy supply: the consumptive water use perspective', 24 International Journal of Water Resources Development 235.

94 Beer, T. et al., 2001, 'Comparison of transport fuels', Final Report (EV45A/2/ F3C) to the Australian Greenhouse Office on the stage 2 study of life-cycle emissions analysis of alternative fuels for heavy vehicles. 
with biofuels. These issues largely relate to the utilization stage, and may have positive or negative environmental impacts, depending on the biofuel and the method of utilization. The impact of increased biofuel use on air quality will have varying significance, depending on the location of the emissions with respect to population centres or sensitive ecosystems. ${ }^{95}$

The use of ethanol as an additive or replacement for gasoline can reduce the emission of air pollutants such as particulates and carbon monoxide. However, concerns with the increasing use of ethanol include increased emissions of acetaldehyde leading to increased ozone and photochemical smog. ${ }^{96}$

Replacing fossil diesel with biodiesel offers advantages for air quality. Biodiesel is an oxygenated fuel, meaning it contains a reduced amount of carbon and higher hydrogen and oxygen content than fossil diesel. This improves the combustion of biodiesel and reduces the particulate, $\mathrm{CO}$ and unburnt hydrocarbon emissions ${ }^{97}$ However, using pure biodiesel may increase NOx-emissions. ${ }^{98}$ Biodiesel contains almost no sulphur and no aromatics. In a properly tuned engine this is expected to lead to lower particulate emissions. ${ }^{99}$

Research by the US Environmental Protection Agency (EPA) shows that while biodiesel reduces most emissions from unmodified diesel engines, the reduction depends on the blend and source of biodiesel. The EPA found that the ozone-forming potential of biodiesel is around half that of regular diesel. The carbon monoxide, particulate matter and hydrocarbons are also lower for biodiesel compared with regular diesel. The exhaust emissions of sulphur oxides and sulphates from biodiesel are essentially eliminated compared with diesel; these pollutants are major

95 Hess, P. et al., 2008, 'Chapter 10: Air Quality Issues Associated with Biofuel Production and Use', in Howarth, R.W. and S. Bringezu (eds), Biofuels: Environmental consequences and interactions with changing land use proceedings of the Scientific Committee on Problems of the Environment (SCOPE) International Biofuels Project Rapid Assessment (Scientific Committee on Problems of the Environment (SCOPE)) <http://cip.cornell.edu/scope/1245782010> (last accessed on 27 October 2015).

96 Grosjean, D., A.H. Miguel and T.M. Tavares, 1990, 'Urban air pollution in Brazil: Acetaldehyde and other carbonyls', 24.1 Atmospheric Environment Part B Urban Atmosphere 101.

97 EPA, 2002, Comprehensive Analysis of Biodiesel Impacts on Exhaust Emissions, Draft Technical Report EPA420-02-001.

98 Nylund, N.-O. and K. Koponen, 2012, 'IEA technology network cooperation: fuel and technology alternatives for buses: overall energy efficiency and emissions', 5 SAE International Journal of Commercial Vehicles 515.

99 Beer, T., T. Grant and P.K. Campbell, 2007, The Greenhouse and Air Quality Emissions of Biodiesel Blends in Australia (CSIRO Marine and Atmospheric Research). 
contributors to acid rain. ${ }^{100}$ The use of modified engines and advanced biodiesel formulations can further reduce emissions of most pollutants and can reduce NOx emissions to levels equivalent to those of regular diesel. ${ }^{101}$ Dufey ${ }^{102}$ concluded that there will generally be no increase in NOx emissions from the use of biodiesel over fossil diesel.

The combustion of raw biomass emits considerable amounts of pollutants, such as particulates and polycyclic aromatic hydrocarbons. Even modern pellet boilers generate more pollutants than oil or natural gas boilers. The combustion of pellets made from agricultural residues can produce higher emissions of dioxins and chlorophenols than wood pellets. ${ }^{103}$

Hess et al. ${ }^{104}$ used a modelling approach to compare the emissions from fuel production and transport for gasoline and various transport biofuels. This LCA modelling found that the air pollution impacts that arise from the production and transport of biofuels can be greater than the equivalent fossil fuel "well-to-pump" emissions for some biofuel production systems. Advanced biofuel production systems can be employed to reduce these emissions, for example, sugar-cane-ethanol systems are moving to green-cane harvesting, avoiding emissions from cane burning prior to harvest.

\subsection{BIODIVERSITY}

The main concerns for biodiversity from biofuels relate to land use change and land occupation for biofuel crops. Biofuels may influence biodiversity directly, or indirectly through market-mediated land use effects. If natural forests and grasslands are cleared, to create land for planting biofuel crops, or as a result of indirect LUC, the biodiversity value of these lands will be substantially impacted. Deforestation in south-east Asia (partly due to growth of biofuels) is estimated to have reduced the area of native forests by $0.23 \%$ and $0.77 \%$ with the annual rate of 677 and 2428 ha/a between 2000 and 2010 and 1990 and 2000, respectively, threatening highly diverse

\footnotetext{
100 Supra, n. 97.

101 McCormick, R.L. et al., 2002, Fuel Additive and Blending Approaches to Reducing NOx Emissions from Biodiesel, No. 2002-01-1658. SAE Technical Paper. 102 Supra, n. 1.

103 Briens, C., J. Piskorz and F. Berruti, 2008, 'Biomass valorization for fuel and chemicals production - a review', 6 International Journal of Chemical Reactor Engineering 5.

104 Supra, n. 95.
} 
and vulnerable ecosystems. ${ }^{105}$ Expansion of biofuel cropping onto native grasslands also threatens biodiversity.

The expansion of oil palm plantations has led to fragmentation and loss of high-value ecosystems and habitats. Species diversity is considerably lower in and around the plantations than in the forests they have replaced. ${ }^{106}$ Also, forest conversion to oil palm plantation leads to significant changes in community composition, which indicates that oil palm plantations are not suitable habitats for the majority of forest animal species. ${ }^{107}$ Direct impacts of sugarcane production on biodiversity are limited, because expansion of cane is occurring at the expense of pasturelands. However, in the future, large-scale expansion of ethanol production might lead to the displacement of natural forests leading to the loss of high-biodiversity areas, and the loss of ecosystem functions. ${ }^{108}$ As with other annual crops, the diversity and abundance of vertebrate species has been found to be lower in corn crops grown for biofuel compared with nearby natural habitats in the USA. ${ }^{109}$ Second-generation biofuel crops, such as switchgrass and Miscanthus, can enhance the biological diversity of agricultural landscapes. ${ }^{110}$

Another concern relates to the risk of biofuel crops becoming weeds. Vigorous crops that are easily propagated naturally present a high risk that they may become significant weeds that could affect agricultural production and/or conservation areas. Arundo donax, for example, has been proposed as a biofuel crop because of its fast growth, yet it is recognized as one of the world's most invasive species. ${ }^{111}$

Biodiversity value may be enhanced by biofuel crops in some circumstances. For example, replacing annual crops with perennial crops can be

105 FAO, 2010, Global Forest Resources Assessment 2010. Main report. FAO Forestry Paper 163 (FAO Rome).

106 Fitzherbert, E.B. et al., 2008, 'How will oil palm expansion affect biodiversity?', 23 Trends in Ecology and Evolution 538; Savilaakso, S. et al., 2014, 'Systematic review of effects on biodiversity from oil palm production', 3 Environmental Evidence 1.

107 Savilaakso, S. et al., ibid.

108 Goldemberg, J., S.T. Coelho and P. Guardabassi, 2008, 'The sustainability of ethanol production from sugarcane', 36 Energy Policy 2086.

109 Fletcher Jr, R.J. et al., 2010, 'Biodiversity conservation in the era of biofuels: risks and opportunities', 9 Frontiers in Ecology and the Environment 161.

110 Werling, B.P. et al., 'Perennial grasslands enhance biodiversity and multiple ecosystem services in bioenergy landscapes', 111 Proceedings of the National Academy of Sciences 1652.

111 Edenhofer, O. et al., 2011, Renewable Energy Sources and Climate Change Mitigation: Special report of the intergovernmental panel on climate change (Cambridge University Press) 270. 
beneficial for in-crop biodiversity because of reduced soil disturbance, lower inputs of fertilizer and pesticides, ongoing organic inputs to the soil, and maintenance of habitat through the year, especially where the biofuel crop is a native species, such as eucalypts in Australia and switchgrass in the USA. Bioenergy plantations can also provide off-site benefits for biodiversity, such as vegetation filters that reduce nutrient pollution of water. ${ }^{12}$ Bioenergy plantations can also play a role in promoting biodiversity when multiple species are planted and mosaic landscapes are established in uniform agricultural landscapes and in degraded areas. ${ }^{113}$ Biofuel plantations of perennial native species could be planted as ecological corridors to reduce the impacts of fragmentation of natural areas. To minimize impacts of biofuel crops on biodiversity, management practices that reduce chemical inputs, increase heterogeneity within fields, and delay harvests until bird breeding has ceased, have been recommended. ${ }^{114}$

Measures to minimize LUC (both direct and indirect), described in section 1.5, "Minimizing ILUC", will also assist in the protection of biodiversity.

Despite the importance of the issue, methods for the assessment of land use-related impacts on biodiversity are not yet fully established. Some preliminary indicators have been proposed to measure biodiversity in life cycle assessment (LCA), for example biodiversity damage potential $(\mathrm{BDP})^{115}$ and "potentially lost non endemic species" (PLNS), based on regional and global potential species extinction. ${ }^{116}$ However, these can be applied only at a coarse scale and are still in development. ${ }^{117}$

112 Foley, J.A. et al., 2005, 'Global consequences of land use', 304 Science 570.

113 Hartley, M.J., 2002, 'Rationale and methods for conserving biodiversity in plantation forests', 155 Forest Ecology and Management 81.

114 Supra, n. 109.

115 de Baan, L., R. Alkemade and T. Koellner, 2013, 'Land use impacts on biodiversity in LCA: a global approach', 18 International Journal of Life Cycle Assessment 1216.

116 de Baan, L. et al., 2013, 'Land use in life cycle assessment: global characterization factors based on regional and global potential species extinction', 47 Environmental Science and Technology 9281.

117 Koellner, T. et al., 2013, 'UNEP-SETAC guideline on global land use impact assessment on biodiversity and ecosystem services in LCA', 18 International Journal of Life Cycle Assessment 1188. 


\subsection{SUMMARY AND RECOMMENDATIONS}

It is likely that global energy demands will increase as world population grows and standards of living rise across developing countries. Climate change challenges make it crucial that alternatives to fossil fuels are developed. Biofuels should be considered as part of the mix of future energy solutions, especially for applications such as long distance road transport and air transport, where other renewable energy options are limited.

Despite the fact that a major driver for biofuel promotion is the assumed climate change benefits, the climate change mitigation value of biofuels has been questioned, from three perspectives. First, there are questions over the balance of emissions generated in the cultivation, processing and use of biofuels relative to the emissions saved. Second, it is claimed that emissions due to indirect land use change may negate the benefit of emissions avoided. Finally, the extent to which biofuels avoid use of fossil fuels is also questioned because of the "rebound effect".

Naturally, climate change concerns necessitate careful evaluation of the potential of biofuels to reduce net climate change effects. Comprehensive comparisons between biofuels and fossil fuels should be undertaken using standardized tools such as Life Cycle Assessment, ensuring that co-products and market impacts are considered. Besides climate change impacts, effects on water resources, soil, air quality and biodiversity should be assessed. While there are examples of biofuel systems that enhance ecosystem services, they may present risks that need to be managed.

Nonetheless, biofuel technologies present a real potential to serve as an alternative to fossil fuels. Decisions to promote specific biofuels should be made on the basis of comprehensive and careful studies that examine the full impacts on all relevant environmental and socio-economic aspects, to avoid perverse outcomes. Uncertainties in the analyses should be characterized and quantified. Policies to support expansion of biofuels should be designed to distinguish and promote beneficial biofuel systems, and minimize the identified risks. The remainder of this book investigates options for regulating biofuels, from theoretical and practical perspectives, and reviews experiences in biofuel governance from around the world. Approaches implemented to date have had mixed success in managing the risks and promoting the opportunities of biofuels, but tools to predict and reduce these risks are rapidly improving. 